\title{
Induction of G1 Arrest by Methanol Extract of Lycopus lucidus in Human Lung Adenocarcinoma A549 Cells
}

\author{
Hyun-jin Park', Soojung Jin', You Na Oh', Seung-Geun Yun ${ }^{1}$, Ji-Young Lee', Hyun Ju Kwon ${ }^{1,2}$ and \\ Byung Woo Kim ${ }^{1,2} \star$
}

\author{
${ }^{1}$ Blue-Bio Industry RIC, Dong-Eui University, Busan 614-714, Korea \\ ${ }^{2}$ Department of Life Science and Biotechnology, College of Natural Sciences, Dong-Eui University, Busan 614714, Korea
}

Received July 10, 2013 /Revised September 16, 2013 /Accepted September 17, 2013

\begin{abstract}
Induction of G1 Arrest by Methanol Extract of Lycopus lucidus in Human Lung Adenocarcinoma A549 Cells Lycopus lucidus, a herbaceous perennial, is used as a traditional remedy in East Asia, including China and Korea. It has been reported that L. lucidus has anti-allergic effects, inhibitory effects on cholesterol acyltransferase in high glucose-induced vascular inflammation, and anti-proliferative effects in human breast cancer cells. However, the molecular mechanisms of the anti-cancer effects of $L$. lucidus have not yet been fully determined. In this study, we evaluated the anti-cancer effect and the mechanism of action of L. lucidus in human lung adenocarcinoma A549 cells using methanol extracts of L. lucidus (MELL). MELL treatment showed cytotoxic activity in a dose-dependent manner and induced G1 arrest in A549 cells. The induction of G1 arrest by MELL was associated with the up-regulation of phospho-CHK2 and the down-regulation of Cdc25A phosphatase. In addition, MELL treatment induced decreased expression of G1/S transition-related proteins, including CDK2, CDK4, CDK6, cyclin D1 and cyclin E. MELL also regulated the mRNA expression of CDK2 and cyclin E. On the other hand, the expression of p53 and the cyclin-dependent kinase inhibitor p21 was not induced by MELL. Collectively, these results suggest that MELL may exert an anti-cancer effect by cell cycle arrest at G1 phase through the ATM/CHK2/Cdc25A/CDK2 pathway in A549 cells.
\end{abstract}

Key words : Anti-cancer effect, Cdc25A, CDK, G1 arrest, Lycopus lucidus

\section{서 론}

암은 선진국에서의 사망의 가장 큰 원인이며 2008년 통계에 따르면 전세계적으로 약 1,200 만 명이 암에 걸렸으며 약 700 만 명이 암으로 사망하였다[18]. 암 발병 및 암으로 인한 사망은 전세계적으로 증가추세에 있으며 국내에서도 식생활의 서구 화, 인구의 급격한 노령화 등으로 인해 그 발병률이 꾸준히 증가하고 있다. 그러나 현대 의학의 발달에도 불구하고 암에 대한 효과적인 치료방법 및 치료제의 개발은 아직까지도 미비 한 실정이다. 따라서 많은 연구자들이 암의 분자적 발생 기전 과 치료방법에 관하여 연구하고 있으며, 암 치료제의 개발을 위해 많은 노력을 기울이고 있다. 특히 폐암의 경우, 남성에서 가장 많이 발병하는 암으로 2008년 새롭게 발병한 암환자의 $17 \%$ 가 폐암이었으며 전체 암사망자의 $23 \%$ 를 차지하였다[18]. 폐암은 주로 외과적인 수술 또는 방사선 요법과 화학요법으로

\footnotetext{
*Corresponding author

Tel : +82-51-890-2900, Fax : +82-51-890-2914

E-mail : bwkim@deu.ac.kr

This is an Open-Access article distributed under the terms of the Creative Commons Attribution Non-Commercial License (http://creativecommons.org/licenses/by-nc/3.0) which permits unrestricted non-commercial use, distribution, and reproduction in any medium, provided the original work is properly cited.
}

치료되나, 표준 화학요법의 경우 암 조직에 대한 낮은 선택성 때문에 정상조직에 여러 부작용을 유발하는 한계가 있다. 따 라서 최근에는 기존 항암제보다 부작용이 적고 새로운 작용기 전을 가지는 식품 또는 천연물 유래 소재의 개발이 활발하게 이루어 지고 있다[8, 25].

고등 진핵세포의 세포주기는 G1, S, G2, M기로 나뉘며 각 주기마다 다음 단계로의 진행에 관여하는 checkpoint가 있어 서 이들 관련인자들의 상호작용을 통하여 세포주기가 조절된 다. 정상세포는 DNA에 손상을 입었을 때 세포주기를 조절하 여 손상된 DNA의 회복 경로를 거친다[16, 27, 39]. 그러나 암 세포에서는 이러한 세포주기 조절 기능이 제어되어 G1/S 또 는 $\mathrm{G} 2 / \mathrm{M}$ 기의 비정상적인 진행에 따른 무한증식이 일어나는 것이 관찰된다[14]. 따라서 최근 암세포의 세포주기를 조절하 는 약물에 관한 연구가 활발히 진행되고 있으며 이러한 연구는 새로운 항암제 개발에 도움이 될 것이다. 최근 연구결과에 따 르면 imidazoacridinone 유도체에 의해 폐암세포의 p53, p21 의 발현이 증가되고 G1 arrest가 유도된다는 보고가 있으며, 또한 창출(Rhizoma Atractylodis) 추출물이 폐암세포의 cyclin $\mathrm{D}$ 의 발현을 감소시키고 G1 arrest를 유도한다는 보고가 있으나 그 정확한 분자 기전에 관하여서는 아직 연구가 미비하다[13, 29]. 세포주기 조절인자 중, 세포주기의 진행을 억제하는 인자로 는 종양억제인자인 p53 및 CDK 억제제로 알려진 p21, p27, 
p16 등이 있다. p53에 의한 세포주기 조절은 가장 활발히 연구 되었으며, DNA 손상에 의해 세포 내 p53의 발현이 유도되고, 유도되어진 p53에 의해 CDK inhibitor인 p21의 발현이 유도 되어 세포주기의 진행이 억제되고 apoptosis가 일어나게 된다 $[1,30,32]$. 또한 p53 비의존적인 p21의 발현에 관한 연구결과 도 있으며, 최근에는 naphthoquinone 유도체를 처리한 간암 세포에서 p53 비의존적으로 p21의 발현이 유도되어 G1 arrest 가 일어난다는 연구결과가 보고되었다[21, 38]. 반면, 세포주기 의 진행을 촉진하는 주요 인자는 인산화 효소인 Cyclin-dependent kinases $(\mathrm{CDKs})$ 와 $\mathrm{CDK}$ 의 활성을 조절하는 $\mathrm{Cyclin}$ 으 로 구성되어 있다. Cyclin과 결합한 $\mathrm{CDK}$ 는 Tyr15 잔기가 인산 화되어 있을 경우 비활성화 되고, 인산화된 Tyr15 잔기의 탈인 산화에 의해 활성화된다 $[6,15,23]$. 이렇게 활성화된 Cyclin$\mathrm{CDK}$ complex는 세포주기를 다음 단계로 진행시킨다. 이때 작용하는 탈인산화효소가 $\mathrm{Cdc} 25$ 단백질이며 $\mathrm{Cdc} 25 \mathrm{~A}$ 는 $\mathrm{G} 1 / \mathrm{S}$ 기에서 cyclinE/CDK2에 작용하여 G1/S 전환을 야기하며, $\mathrm{Cdc} 25 \mathrm{C}$ 는 $\mathrm{G} 2 / \mathrm{M}$ 기에서 cyclinB/Cdc2 complex를 활성화시 킨다 $[7,19,26]$. 특히 비소세포성 폐암, 두경부암과 유방암 환 자들에게서 이들 탈인산화효소인 $\mathrm{Cdc} 25 \mathrm{~A}$ 및 $\mathrm{Cdc} 25 \mathrm{~B}$ 가 과발 현되어 있으며, $\mathrm{Cdc} 25 \mathrm{~A}$ 의 발현을 저해시켰을 때 간암세포의 성장과 침투가 억제되었다는 보고가 있어, $\mathrm{Cdc} 25$ 단백질의 활성 억제제를 찾는 것이 새로운 기전의 항암치료제 개발의 중요한 분야로 대두되고 있다[12, 17, 34].

택란(Lycopus lucidus Turcz.)은 꿀풀과의 쉽싸리의 꽃이 피 기 전 지상부를 말하며, 우리나라를 포함하여 중국, 일본 등 동아시아에 널리 분포하는 다년생 식물이다. 피를 잘 순환하 게 하여 수 세기 동안 동양 의학에서 어혈을 풀어주는 약재로 사용되었으며 특히 강장제, 무월경증 치료제, 산후복통, 통증 완화제 등으로 널리 사용되고 있다 $[5,28]$. 택란의 생리활성에 관한 연구로는 택란 구성성분의 항산화효과 및 추출물의 항염 증 효과가 보고되어 있으며, 알러지 모델을 사용하여 mast cell 에 의한 택란 열수추출물의 항알러지 효과를 분석한 연구결과 가 보고되었다[22, 31, 33, 37]. 최근 연구결과에 따르면 택란 추출물이 유방암 세포 MCF-7의 apoptosis를 유도하여 성장을 저해한다는 보고가 있으나, 다른 종류의 암세포에서의 항암활 성 및 세포주기 조절에 의한 항암활성에 관한 명확한 분자적 기전 연구는 아직 미비하다[20]. 따라서 본 연구에서는 인간 폐암세포 A549를 사용하여 택란 메탄올 추출물의 A549 세포 의 성장에 미치는 영향 및 세포주기조절에 의한 항암활성과 그 분자적 기전에 관하여 연구하였다.

\section{재료 및 방법}

시료준비

본 실험에서 사용한 택란(Lycopus lucidus Turcz.)은 국내산 (경상북도 영천시)이며 (주) 대한생약제품(부산광역시 소재)에
서 구입하였다. 택란 $10 \mathrm{~g}$ 을 파쇄하여 분말로 만든 후 시료의 5-10배의 메탄올 용매를 가하여 $75^{\circ} \mathrm{C}$ 에서 3 회 반복 추출했다 (수율: $12.8 \%$ ). 획득한 메탄올 추출물(Methanol extracts of Lycopus lucidus Turcz., MELL)을 Whatman No.2 (Whatman international Ltd., England)에 여과 후 감압 농축기로 농축하 여 $1.28 \mathrm{~g}$ 을 얻었으며, 동결건조(FDU-2100, EYELA, Japan) 하 여 $200 \mathrm{mg} / \mathrm{ml}$ 의 농도로 dimethylsulfoxide (DMSO, Sigma) 에 용해시켜 상온에 보관하고 세포에 처리 전 배지에 희석하 여 사용하였다.

\section{세포배양}

실험에 사용된 인체 폐암 세포주 A549는 American Type Culture Collection (ATCC, USA)으로부터 구입하였으며, Dulbecco's modified Eagle's medium (DMEM) 배지에 10\% fetal bovine serum (FBS)와 penicillin/streptomycin을 첨가하 여 사용하였고, $37^{\circ} \mathrm{C}$ 배양기에서 $5 \%$ 의 $\mathrm{CO}_{2}$ 를 유지하면서 배 양하였다.

\section{WST assay에 의한 세포 성장억제 조사}

MELL이 폐암세포의 성장에 미치는 영향을 확인하기 위하 여 WST (water soluble tetrazolium salt) assay를 수행하였다. 인체 폐암 세포주인 A549를 24-well plate에 1-3×10 cells/ well로 분주한 후 24시간 뒤 MELL을 농도별 $(0-800 \mu \mathrm{gg} / \mathrm{ml})$ 로 처리하고 24 시간 및 48 시간 동안 배양하였다. 세포의 배지를 제거하고 WST 시약(Daeillab, Korea)이 포함된 배지를 분주 후 30 분간 $37^{\circ} \mathrm{C}$ 배양기에서 반응시키고 microplate reader (Molecular Devices, Sunnyvale, CA, USA)로 $450 \mathrm{~nm}$ 에서 흡 광도를 측정하였다. 측정값은 3 회 반복 실험을 하여 평균값으 로 나타내었으며, 본 실험결과를 바탕으로 이후 적정 처리 농 도를 결정하였다.

\section{택란(Lycopus /ucidus Turcz.) 처리에 의한 세포의 형태} 변화 관찰

MELL에 의한 A549 세포의 형태학적 분석을 위하여 6-well plate에 $3 \times 10^{5}$ cells/well의 A549 세포를 분주하고 24 시간 뒤 MELL을 농도별 $(0-400 \mu \mathrm{g} / \mathrm{ml})$ 로 처리 후 48 시간 동안 배양하 였다. 도립현미경을 사용하여 100-200배의 배율로 관찰했으 며, Axio Vision program을 사용하여 촬영을 하였다.

\section{Flow cytometry에 의한 세포주기 분석}

MELL이 A549 세포주기에 미치는 영향에 대한 분석을 위하 여 MELL을 다양한 농도로 A549 세포에 처리하여 CycleTEST TM PLUS DNA Reagent Kit (Becton Dickinson, San Jose, CA, USA)로 세포주기를 분석하였다. 세포는 6-well plate에 $3 \times 10^{5}$ cells/well의 농도로 분주하였고 MELL의 농도는 $0-400 \mathrm{\mu g} / \mathrm{ml}$ 로 처리 후 24시간 동안 배양하여 PBS로 세척하고 ribonu- 
clease $\mathrm{A}$ 를 실온에서 10 분간 처리한 다음 propidium iodide (PI) 용액을 첨가하여 $4^{\circ} \mathrm{C}$ 에서 10 분간 염색하였다. 염색된 세 포는 Flow cytometry (Cell Lab Quanta SC, Beckman Coulter, Fullerton, CA, USA)로 측정하였으며, WinMDI2.8 program을 사용하여 분석하였다.

\section{$\mathrm{RT}-\mathrm{PCR}$ 에 의한 mRNA 발현 분석}

MELL 처리에 의한 A549 세포의 세포주기에 관련된 mRNA 의 발현 양상을 확인하기 위하여 RT-PCR을 수행하였다. A549 세포에 농도별 $(0-400 \mathrm{\mu g} / \mathrm{ml})$ 로 MELL을 처리하고 24시간 배 양 후 TRIzol reagent (Invitrogen Co., Carlsbad, CA)을 이용 하여 total RNA를 분리하였다. 분리된 RNA를 $1 \mu \mathrm{g}$ 으로 정량 한 후 oligo dT primer와 SuperScript First-Strand Synthesis System kit (Invitrogen Co., Carlsbad, CA)를 사용하여 cDNA 를 합성하였으며, 이 $\mathrm{cDNA}$ 를 template로 사용하여 $\mathrm{CDK} 2$, CDK4, Cyclin E, Cyclin D1 유전자를 TaKaRa Taq kit (TaKaRa biotechnology, DALIAN, Co., LTD.)로 증폭하였다. 이 때 housekeeping 유전자인 $\beta$-actin을 internal control로 사 용하였으며, 각 PCR 산물에 DNA gel loading solution을 섞어 서 $1 \%$ agarose gel을 이용하여 전기영동하고 ethidium bromide (EtBr, Sigma)로 염색한 후 UV 하에서 확인하였다.

\section{Western blot에 의한 단백질 발현 분석}

MELL을 처리한 A549 세포의 세포주기에 관련된 단백질의 발현 양상을 확인하기 위하여 Western blot을 수행하였다. $\mathrm{A} 549$ 세포에 농도별 $(0-400 \mathrm{\mu g} / \mathrm{ml})$ 로 MELL을 처리하고 24시 간 배양하였으며 PBS로 세척 후 lysis buffer (Cell Signaling Technology MA, USA/1 mM PMSF)를 첨가하여 세포를 회수 하였다. 회수된 세포는 $4{ }^{\circ} \mathrm{C}$ 에서 20 분 동안 반응 후 $14,000 \times$ $g$ 에서 10 분간 원심분리하여 상층액을 취하였다. Bradford assay로 정량한 $30 \mu \mathrm{g}$ 의 단백질은 sodium dodecyl sulfate (SDS)-polyacrylamide gel을 이용하여 전기영동으로 분리하 고 nitrocellulose membrane에 transfer한 후 5\% skim milk가 함유된 TBS-T를 사용하여 상온에서 30분 동안 blocking을 하 고 일차항체를 $44^{\circ} \mathrm{C}$ 에서 15 시간 반응시킨 다음, horse radish peroxidase (HRP)가 부착된 이차항체(Santa Cruz Biotechnology, CA, USA)를 상온에서 30 분간 반응시켰다. 반응이 끝난 후 Western blotting luminol reagent (Santa Cruz Biotechnology, CA, USA)를 membrane에 도포하고 chemiluminescence detection system (FluoChem ${ }^{\circledR}$ FC2, AlphaInnotech, USA)을 사용하여 분석하였다. 본 실험에 사용한 p53, p27, CDK2, CDK4, CDK6, Cyclin E, Cyclin D1, actin에 대한 일차항체는 Santa Cruz Biotechnology (CA, USA)에서 구입하 였으며, p21, CHK2, p-CHK2, CDC25A에 대한 일차항체는 Cell Signaling Technology (MA, USA)에서 구입하여 사용하 였다.

\section{택란 처리에 의한 DNA damage 분석}

MELL에 의해 DNA damage가 일어나는지 확인하기 위하 여 agarose gel 전기영동에 의한 정성적 분석을 수행하였다. 먼저 A549 세포에 $2 \mathrm{mM}$ hydrogen peroxide $\left(\mathrm{H}_{2} \mathrm{O}_{2}\right)$ 와 MELL 을 농도별 $(100-400 \mu \mathrm{g} / \mathrm{ml})$ 로 처리하고 24시간 배양 후 세포를 회수하여 AccuPrep® Genomic DNA Extraction Kit (Bioneer, Korea)를 사용하여 genomic DNA를 분리한 다음, $1 \%$ agarose gel을 이용하여 전기영동하였다. DNA는 EtBr로 염색한 후 $\mathrm{UV}$ 하에서 확인하였다.

\section{결 과}

\section{$\mathrm{MELL}$ 의 세포 성장 억제 효과}

폐암 세포주인 A549의 성장에 미치는 MELL의 영향을 알아 보기 위하여 적정농도의 MELL을 처리하고 24시간 및 48시간 배양 후 WST assay를 실시하였다. 그 결과, Fig. 1A에 나타난 바와 같이 농도의존적으로 세포의 생존율이 감소하였으며, 특 히 48 시간 처리한 경우 $200 \mathrm{\mu g} / \mathrm{ml}$ 에서는 약 $50 \%$ 정도의 생존 율 억제가 일어났고, 최고농도인 $600 \mathrm{\mu g} / \mathrm{ml}$ 에서는 $60 \%$ 이상 의 성장 억제 효과를 보였다. 또한, MELL 처리에 따른 A549 세포의 형태 변화를 관찰하기 위하여, MELL을 농도별로 48시 간 처리한 다음 도립현미경을 이용하여 A549 세포의 형태를 관찰하였다. 그 결과, MELL 처리 농도가 증가할수록 A549의 세포 형태가 변화되며 세포의 수가 감소하는 것을 확인할 수 있었다(Fig. 1B). 이들 결과로부터 MELL은 A549의 세포 성장 을 억제함을 알 수 있었다.

\section{MELL에 의한 G1 arrest 유도}

MELL의 A549 세포주기에 미치는 영향을 알아보기 위하여 적정농도의 MELL을 세포에 처리하고 24시간 배양 후 Flow cytometry를 사용하여 세포주기 변화를 측정하였다. Fig. 2A 의 histogram 결과와 같이 MELL 처리 농도가 높아질수록 G1 기(region M2)의 세포분포가 점차 증가하는 것을 알 수 있었 다. 반면, S기(region M3) 및 G2/M기(region M4)의 세포는 MELL 농도 의존적으로 감소함을 확인하였다. 또한 Fig. $2 \mathrm{~B}$ 에 서 나타낸 바와 같이 각 주기별 실제 세포분포수를 확인한 결과, DMSO 대조군에서는 $58.14 \%$ 였던 G1기 세포분포는 MELL의 농도의존적으로 증가하여 최고 농도인 $400 \mu \mathrm{g} / \mathrm{ml}$ 에 서는 $84.57 \%$ 의 A549 세포가 G1기에 정체되어 있음을 알 수 있었다. 상대적으로 G1기 이후 단계인 S기 및 G2/M기의 세포 는 각각 $21.48 \%$ 에서 $10.2 \%$ 로, $10.38 \%$ 에서 $2.75 \%$ 로 감소하였 다. 따라서 본 결과는 MELL의 처리에 의해 A549 세포의 강력 한 G1 arrest가 유도됨을 시사한다.

MELL에 의한 세포주기 관련 인자들의 발현 변화 분석 앞서 Fig. 2에서 MELL에 의한 A549 세포의 G1 arrest 유도 


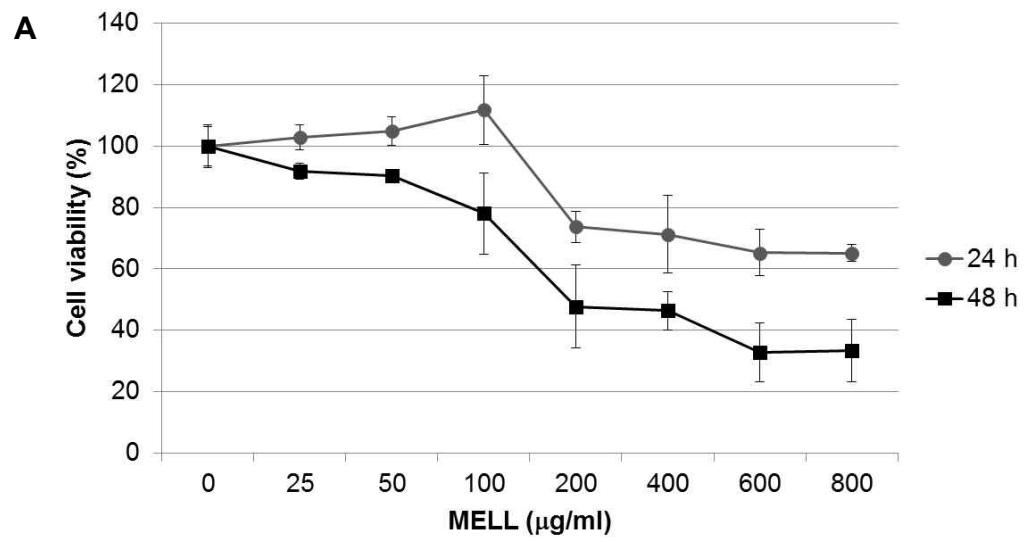

B

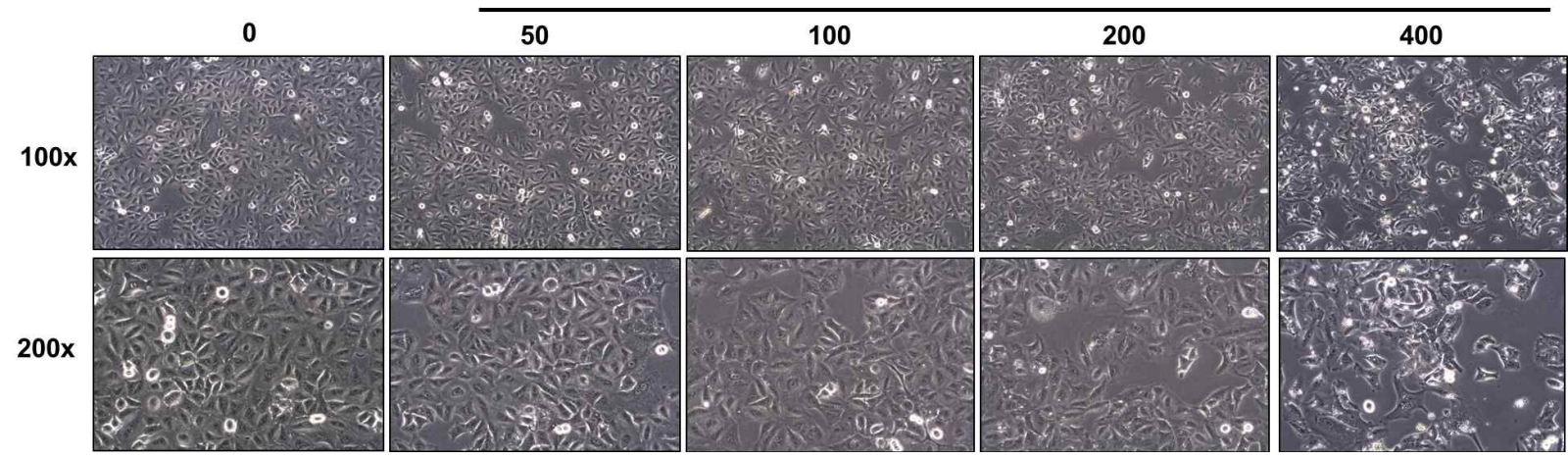

Fig. 1. Effects of MELL on cell growth and cell morphology in human lung carcinoma A549 cells. (A) Cells were treated with various concentration of MELL for 24 and $48 \mathrm{hr}$. Cytotoxic effect of MELL was determined by WST assay. Results are expressed as percentage of the vehicle treated control \pm SD of three independent experiments. (B) Morphological changes by MELL treatment. Cells were treated with various concentration of MELL for $48 \mathrm{hr}$, and then visualized by light microscopy. Magnification, $\times 100$ and $\times 200$.

A

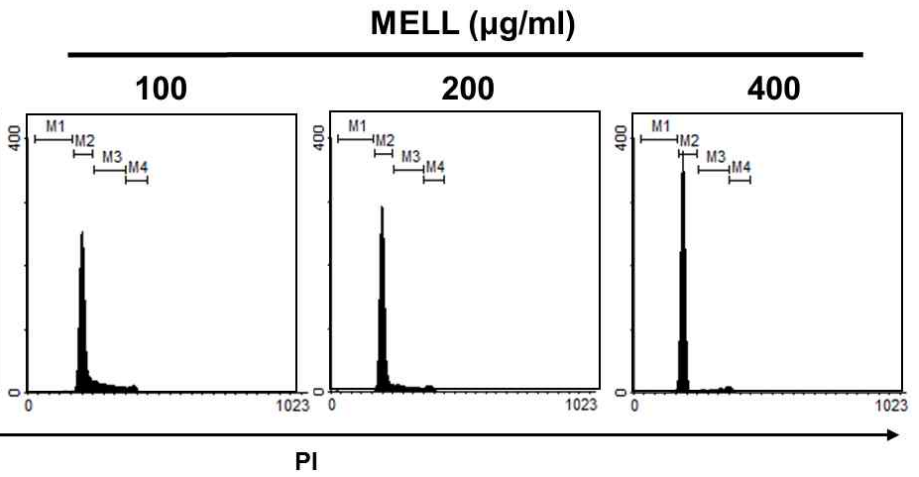

B

\begin{tabular}{ccccc}
\hline \multirow{2}{*}{$\begin{array}{c}\text { MELL } \\
(\mu \mathrm{g} / \mathrm{ml})\end{array}$} & Sub G1 & G1 & \multicolumn{1}{c}{$\mathrm{S}$} & $\mathrm{G}$ of cell \\
\cline { 2 - 5 } & 3.46 & 58.14 & 21.48 & 10.38 \\
100 & 2.76 & 69.42 & 21.82 & 6.39 \\
200 & 2.4 & 76.8 & 15.1 & 5.8 \\
400 & 2.56 & 84.57 & 10.2 & 2.75 \\
\hline
\end{tabular}

Fig. 2. G1 arrest of cell cycle in MELL-treated A549 cells. A549 cells were cultured and treated with MELL for 24 hr. Cells were harvested, and then stained with propidium iodide for $30 \mathrm{~min}$ and analyzed by flow cytometry. DNA-flourescence histogram (A) and quantitative data of cell distribution (B) are shown. 
를 확인하였으므로, 다음으로 분자적 레벨에서 더욱 명확하게 분석하기 위하여 MELL을 24시간 동안 처리한 후 세포주기 관련 단백질인 cyclin과 $\mathrm{CDK}$ 의 발현량을 Western blot analy$\mathrm{sis}$ 를 통해 확인하였다. 그 결과, Fig. $3 \mathrm{~A}$ 에서와 같이 G1기에서 $\mathrm{S}$ 기로의 전환을 촉진하는 단백질인 cyclin D1과 cyclin E의 발현이 감소하였으며, cyclin과 반응하여 G1기에서 S기로의 전환을 유도하는 cyclin-dependent kinase인 CDK2, CDK4, $\mathrm{CDK} 6$ 의 발현 또한 MELL 농도의존적으로 감소하였다. 특히 $\mathrm{CDK} 2$ 와 cyclin E의 경우, MELL처리에 의해 mRNA 레벨에서 억제되어 단백질 발현이 감소되는 것을 RT-PCR을 통하여 확 인하였다(Fig. $3 \mathrm{~B}$ ). 반면 CDK4 및 cyclin D1의 발현은 mRNA 레벨에서는 변화가 없었다. 이와 같은 결과로부터 MELL은 cyclin과 CDK의 발현 감소를 통하여 A549의 G1 arrest를 유도 한다는 것을 알 수 있었다.

\section{MELL에 의한 G1 arrest 기전 분석}

다음으로 MELL 처리에 의한 A549 세포의 G1 arrest의 상 위기전 분석을 위하여 종양억제유전자인 p53, CDK inhibitor 인 p21과 p27, CDK activator인 Cdc25A 그리고 CHK2의 단백 질 발현을 Western blot analysis를 통하여 확인하였다. 그 결 과 Fig. $4 \mathrm{~A}$ 에서와 같이 MELL 농도의존적으로 $\mathrm{CHK} 2$ 의 발현
이 감소되었으며, DNA damage에 의해 활성화되는 p-CHK2 의 발현은 증가되었다. 또한 $\mathrm{CDK}$ 를 탈인산화시켜 활성화시키 고 G1/S 전환을 유도하는 Cdc25A phosphatase의 발현이 MELL 농도의존적으로 감소되었다. 반면 p53, p21 및 p27의 발현증가는 관찰되지 않았다(Fig. $4 \mathrm{~B})$. 이와 같은 결과로부터 MELL은 CHK2의 인산화를 유도하여 그 down signal인 Cdc25A phosphatase 발현을 저해하는 것을 알 수 있었으며, 그 결과 inactive form $\mathrm{CDK}$ 의 탈인산화가 억제되어 $\mathrm{CDK} / \mathrm{cy}$ clin complex가 저해되고 A549 세포의 G1 arrest가 유도되었 을 것으로 사료된다. 또한 이러한 MELL 처리에 의한 G1 arrest는 일반적으로 관찰되는 p53 경로 관련 단백질들의 발현 증가가 관찰되지 않았으므로 $\mathrm{p} 53$ 비의존적인 것이라 생각된다.

\section{MELL에 의한 DNA damage 유발}

다음으로 MELL 처리에 의해 유도된 CHK2의 인산화가 DNA damage에 의한 것인지 확인하였다. 먼저 A549 세포에 MELL을 농도별로 24시간 처리하고, 이때 양성 대조군으로 $\mathrm{A} 549$ 세포에 $2 \mathrm{mM}$ 의 $\mathrm{H}_{2} \mathrm{O}_{2}$ 를 처리하여 genomic DNA를 추 출하였다. 추출한 DNA를 $1 \%$ agaroge gel 전기영동으로 확인 한 결과, Fig. 5 에서와 같이 DMSO을 처리한 대조군에 비해 MELL을 처리한 경우, A549 세포의 DNA에 damage가 일어나
A

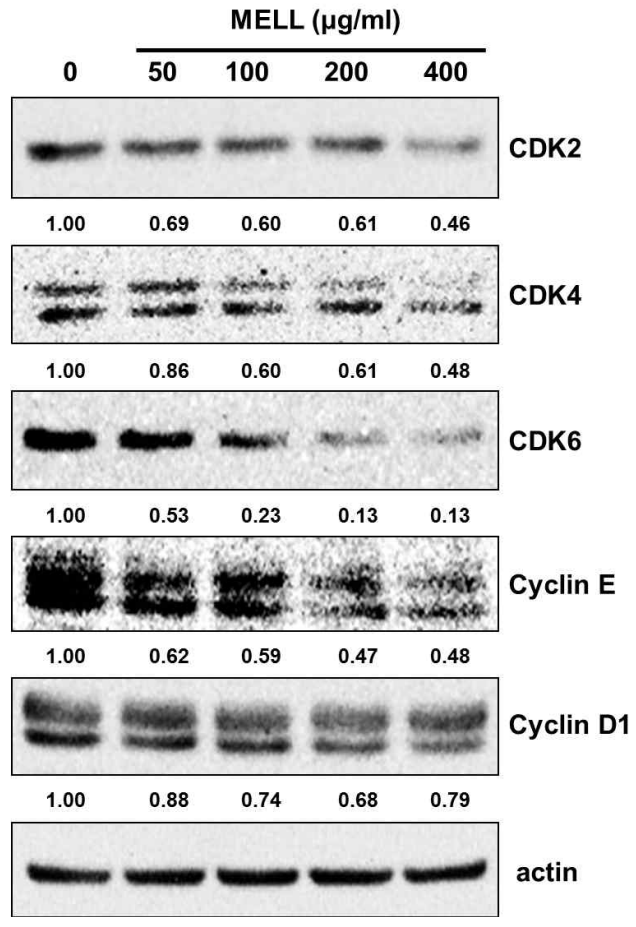

B

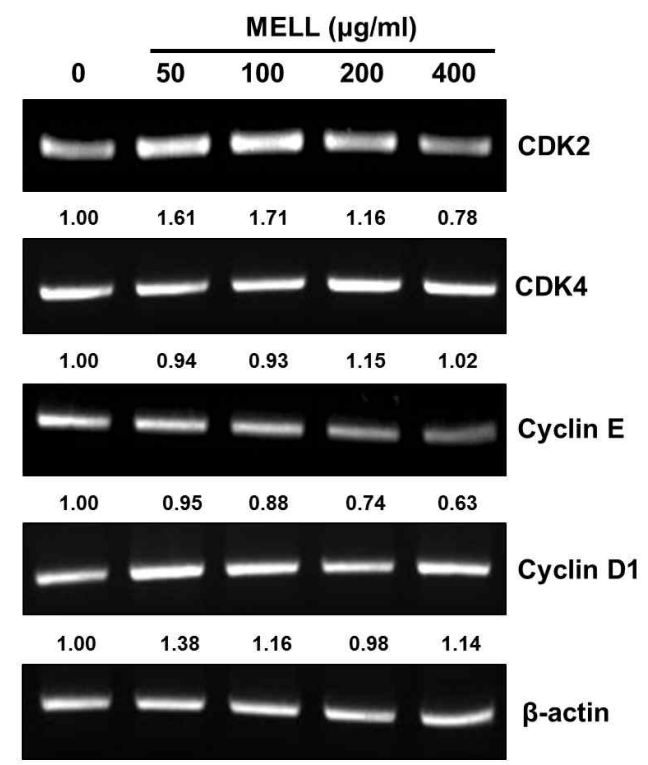

Fig. 3. Downregulation of G1 checkpoint proteins by MELL treatment in A549 cells. (A) Cells were treated with various concentrations of MELL for $24 \mathrm{hr}$. The cells were lysed and cellular proteins were then separated by SDS-PAGE, followed by Western blotting using antibodies against CDK2, CDK4, CDK6, cyclin D1 and cyclin E. Actin was used as an internal control. (B) A549 cells were cultured and treated with MELL for $24 \mathrm{hr}$. First strand cDNA was synthesized by reverse transcriptase enzyme and PCR reaction was carried out using primers for CDKs and cyclins. Numerical bottom panel of each band indicates the fold change in the band intensity compared with that of control. 
A

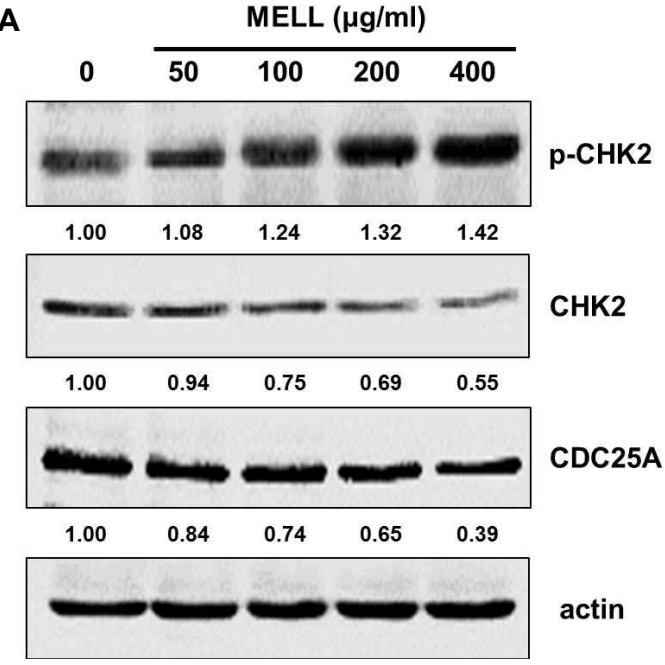

B

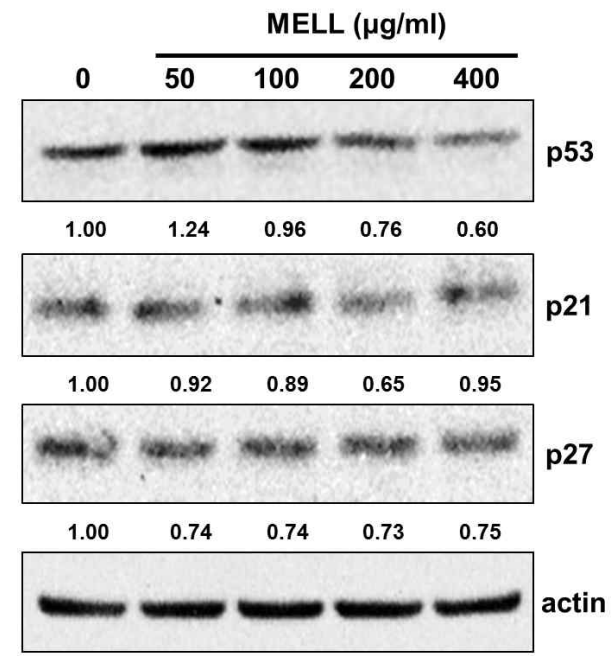

Fig. 4. Effects of MELL on the expression of upstream signal proteins leading to G1 arrest in A549 cells. Cells were harvested and lysed after incubation with the indicated doses of MELL for $24 \mathrm{hr}$. The cellular proteins were subjected to Western blot analysis with anti-p-CHK2, anti-CHK2, and anti-CDC25A antibodies (A) and p53 pathway-related protein antibodies (B). Numerical bottom panel of each band indicates the fold change in the band intensity compared with that of control.

genomic DNA band의 intensity가 control에 비해 $60-70 \%$ 감 소하는 것을 알 수 있었다. 또한 MELL에 의한 A549 세포의 DNA damage는 MELL의 농도가 증가할수록 더 많이 유발되 는 것을 알 수 있었다. 이상의 결과로부터 MELL에 의해 A549 세포의 DNA damage가 일어나고 그로 인해 CHK2의 인산화 가 유도되어 G1 arrest가 유발되는 것이라 사료된다.

\section{고 찰}

현재 전세계적으로 암의 발병률 및 사망률이 계속 증가되고 있는 추세이나 그에 비해 현대 의학의 발전에도 불구하고 효 과적이고 부작용이 적은 항암제 및 치료법의 개발이 부족한 실정이다. 따라서 기존의 항암제보다는 독성이 적고 암세포에 대한 특이성이 높은 새로운 작용기전을 가지는 항암제의 개발 이 요구되고 있으며, 암의 발병기전에 관한 분자생물학적 연 구 및 다양한 기전의 항암 활성을 가지는 천연물 소재에 관한 연구가 활발하게 진행되고 있다. 특히 암세포에서 특이적으로 과발현되어 있는 세포주기조절 관련 분자 등에 관한 연구결과 들이 보고되면서 세포주기조절 인자를 target으로 하는 항암 제에 관한 연구가 주목받고 있다. 이에 본 연구에서는 인체 폐암 세포인 A549를 사용하여 한약재인 택란 메탄올 추출물 (MELL)의 항암효과 및 그 분자생물학적 기전연구로서 세포주 기 조절에 관하여 분석하였다.

MELL의 A549 생존율 및 증식억제를 확인한 결과, MELL이 포함된 배지에서 48시간 동안 배양하였을 때 MELL 처리 농도 및 시간 의존적으로 생존율이 감소하였으며, 세포 형태의 변 화와 세포 수 감소를 현미경으로 관찰할 수 있었다(Fig. 1). 이러한 생존율 감소의 기전을 확인하기 위하여 세포주기 변화
를 관찰하였으며 그 결과 MELL 농도의존적으로 G1 arrest가 일어나는 것을 알 수 있었다(Fig. 2).

정상세포에서는 DNA damage가 일어나는 경우, 세포주기 의 checkpoint 단백질들의 활성을 조절하여 세포주기 진행을 제어한다. 그러나 암세포에서는 이러한 세포주기 제어로부터 벗어나 무한 증식을 가능하게 한다. 정상세포에서의 세포주기 조절 기전 중 하나인 종양억제유전자 $\mathrm{p} 53$ 의 경우, $\mathrm{p} 53$ 의 발현 이 증가되면 그 다음으로 $\mathrm{CDK}$ 억제제인 p21 및 p27의 발현이 증가되고 이들은 세포주기진행을 촉진하는 $\mathrm{CDK}$ 를 억제하여 세포주기 진행을 저해한다. 최근에는 또 다른 기전인 $\mathrm{Cdc} 25$ 단백 질에 관한 연구가 활발히 진행되고 있으며, 다양한 암세 포에서 Cdc25 단백질의 과발현이 관찰되었고 이들은 oncogene으로 작용한다는 연구결과가 보고되었다[11]. Cdc25 단 백질 family 중 하나인 Cdc25A는 CDK2의 탈인산화를 유도하 여 $\mathrm{CDK} 2$ 를 활성화시키고 $\mathrm{G} 1 / \mathrm{S}$ 전환을 통해 세포주기 진행을 촉진한다[4]. 또한 인간 비소세포성 폐암 및 hepatocellular carcinoma cell (HCC) 조직샘플에서 Cdc25A의 과발현이 관 찰되었으며 이것은 암세포의 증식, 혈관침투등과 연관되어 있 고, $\mathrm{Cdc} 25 \mathrm{~A}$ 를 저해하였을 때 $\mathrm{HCC}$ 의 성장 및 침투가 억제된 다는 보고가 있다 $[35,36]$. 그 외에도 $\mathrm{Cdc} 25 \mathrm{~A}$ 의 발현 저해에 의해 암세포의 G1 arrest가 유도된다는 연구결과가 있다[3]. 이러한 Cdc25 단백 질들은 DNA damage checkpoint와의 연 관성이 커서, 사람의 세포에서는 ATM/CHK2/Cdc25A/ $\mathrm{Cdk} 2$ 경로가 방사선 조사에 의한 DNA 합성을 막는 데 필요 하다는 보고가 있다[10]. 즉, 방사선 조사에 따른 이중나선에 끓김이 생긴 경우, 세포는 ATM kinase를 활성화시키고 활성 화된 $\mathrm{ATM}$ 에 의해 $\mathrm{CHK} 2$ 의 인산화가 유도되어 $\mathrm{CHK} 2$ 가 활성 화된다. 활성화된 $\mathrm{CHK} 2$ 는 다음으로 $\mathrm{Cdc} 25 \mathrm{~A}$ 를 인산화시키고 
인산화된 $\mathrm{Cdc} 25 \mathrm{~A}$ 는 ubiquitin-dependent proteasomal degradation을 일으킨다. 따라서 ATM/CHK2 경로를 통한 $\mathrm{Cdc} 25 \mathrm{~A}$ 의 불활성화는 손상된 세포에서의 세포주기 진행을 막는 데 중요한 역할을 하며, ATM, CHK2 등의 돌연변이에 의해 DNA damage에 따른 Cdc $25 \mathrm{~A}$ 의 분해가 이루어지지 않 으면 암세포로 발전할 가능성이 매우 높아진다[2].

따라서 본 연구에서는 MELL에 의한 A549의 G1 arrest 유 도의 분자생물학적 기전을 분석하기 위해 cyclin, $\mathrm{CDK}$ 등 checkpoint 단백질들과 CHK2, Cdc25A, p53, p21 등의 발현을 확인하였다. 예상대로 MELL 처리에 따라 농도의존적으로 cyclin $\mathrm{D} 1$, cyclin $\mathrm{E}, \mathrm{CDK} 2, \mathrm{CDK} 4$ 등 $\mathrm{G} 1 / \mathrm{S}$ 전환에 관련하는 단백질들의 발현이 감소하였다(Fig. 3). 특히 CDK2, cyclin E의 경우 mRNA 발현 또한 감소하여 전사단계에서의 발현 저해가 일어남을 뜻하며, CDK4, cyclin D1의 경우 mRNA 발현은 감 소되지 않아 생성된 단백질의 안정성 조절 또는 ubiquitination 등 번역 후 조절에 의한 발현 저해일 것이라 사료된다. 또한 활성화된 CHK2인 p-CHK2의 발현은 증가되고 Cdc25A 의 발현은 감소하였으며(Fig. 4A), MELL 처리에 의해 A549 세포의 DNA damage가 일어나는 것을 확인하였다(Fig. 5). 이 러한 결과들은 MELL 처리에 의해 DNA damage가 일어나 $\mathrm{CHK} 2$ 가 활성화되고, 활성화된 CHK2 kinase는 Cdc25A의 인 산화를 유도하여 ubiquitin에 의한 $\mathrm{Cdc} 25 \mathrm{~A}$ 의 분해를 유도하 였음을 시사한다. 반면 일반적인 항암활성의 기전 중 하나인 p53 pathway 관련 단백질들의 발현 변화를 알아본 결과, MELL 처리에 의해 p53, p21, p27 등의 발현이 증가되지 않았 다(Fig. 4B). 지금까지의 결과들을 종합하여 볼 때, MELL 처리 에 의한 A549 세포의 G1 arrest는 p53 비의존적으로 유도되며, DNA damage에 의한 ATM/CHK2 pathway의 활성화에 따

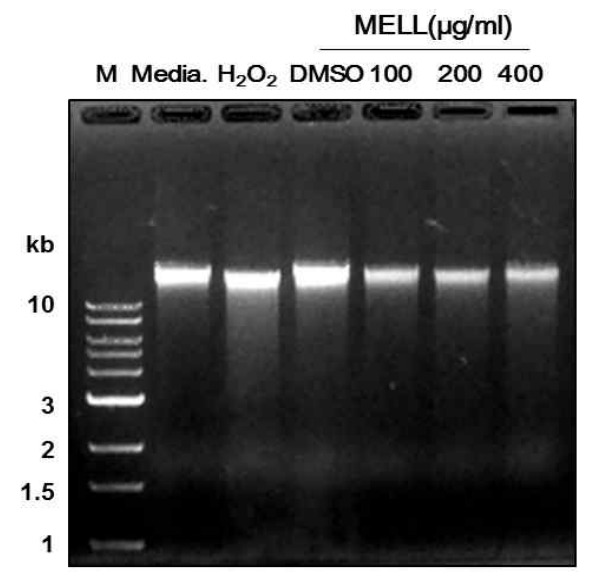

Fig. 5. Detection of cellular DNA damage in A549 cells treated with MELL. Cells were treated with various concentrations of MELL for $24 \mathrm{hr}$. As a positive control for DNA damage, $2 \mathrm{mM} \mathrm{H}_{2} \mathrm{O}_{2}$ was treated to A549 cells for 24 $\mathrm{hr}$. Genomic DNA was isolated and electrophoresed in $1 \%$ agarose gel.
라 $\mathrm{Cdc} 25 \mathrm{~A}$ 의 발현량이 줄어들고 그 결과 $\mathrm{CDK} / \mathrm{Cyclin}$ complex의 불활성화가 일어나게 되어 최종적으로 $\mathrm{G} 1 \mathrm{arrest}$ 가 유 도된다고 사료된다. 이러한 $\mathrm{p} 53$ 비의존적인 세포주기조절에 관하여서는 human melanoma cell에서 Interleukin-1 (IL-1)에 의해 p53-, p21- 비의존적인 G1 arrest가 일어난다는 연구 보고 가 있으며 또한 $\mathrm{p} 14^{\mathrm{ARF}}$ 가 genotoxic stress에 대해 $\mathrm{p} 53$ 비의존 적으로 ATM/ATR/CHK pathway를 활성화시켜 G2 arrest를 일으킨다는 보고가 있으나, 그 정확한 기전에 관하여는 더욱 연구되어야 할 것이다[9, 24]. 특히 폐암세포의 세포주기조절 을 유발하는 약물에 관한 연구는 p53 및 p21의 발현유도에 의한 $\mathrm{G} 1 \mathrm{arres}$ 에 관한 연구결과가 대다수이므로, 본 연구 결 과가 택란 추출물의 세포주기 조절에 의한 항암기전을 해석하 고 폐암세포의 세포주기 조절의 새로운 기전연구를 위한 중요 한 기초자료가 될 것이라 사료된다. 또한 본 연구결과를 바탕 으로 하여 나아가 동물실험을 통한 실질적인 택란 추출물의 항암활성에 관한 연구도 지속되어야 할 것이다.

\section{감사의 글}

본 연구는 산업통상자원부·부산광역시 지원 지역혁신센터 사업(RIC08-06-07) 동의대학교 블루바이오 소재 개발 및 실용 화 지원 센터의 지원으로 이루어 졌습니다.

\section{References}

1. Bartek, J. and Lukas, J. 2001. Pathways governing G1/S transition and their response to DNA damage. FEBS Lett 490, 117-122

2. Bernardi, R., Liebermann, D. A. and Hoffman, B. 2000. Cdc25A stability is controlled by the ubiquitin-proteasome pathway during cell cycle progression and terminal differentiation. Oncogene 19, 2447-2454.

3. Bertero, T., Gastaldi, C., Bourget-Ponzio, I., Mari, B., Meneguzzi, G., Barbry, P., Ponzio, G. and Rezzonico, R. 2013. Cdc25A targeting by miR-483-3p decreases CCNDCDK4/ 6 assembly and contributes to cell cycle arrest. Cell Death Differ 20, 800-811.

4. Biomberg, I. and Hoffmann, I. 1999. Ectopic expression of Cdc25A accelerates the $G(1) / S$ transition and leads to premature activation of cyclin E- and cyclin A-dependent kinases. Mol Cell Biol 19, 6183-6194.

5. But, P. P. H., Kimura, T., Sung, C. K. and Han, B. H. 1997. International collation of traditional folk medicine, pp. 137, Vol. 3, World scientific: New Jersey, USA.

6. Coulonval, K., Nockstaele, L., Paternot, S. and Roger, P. P. 2003. Phosphorylations of cyclin-dependent kinase 2 revisited using two-dimensional gel electrophoresis. $J$ Biol Chem 278, 52052-52060.

7. Donzelli, M. and Draetta, G. F. 2003. Regulating mammalian checkpoints through $\mathrm{Cdc} 25$ inactivation. EMBO Rep 4, 671-677. 
8. Dorai, T. and Aggarwal, B. B. 2004. Role of chemopreventive agents in cancer therapy. Cancer Lett 215, 129-140.

9. Eymin, B., Claverie, P., Salon, C., Leduc, C., Col, E., Brambilla, E., Khochbin, S. and Gazzeri, S. 2006. p14ARF activates a Tip60-dependent and p53-independent ATM/ATR/CHK pathway in response to genotoxic stress. Mol Cell Biol 26, 4339-4350.

10. Falck, J., Mailand, N., Syljuasen, R. G., Bartek, J. and Lukas, J. 2001. The ATM-Chk2-Cdc25A checkpoint pathway guards against radioresistant DNA synthesis. Nature 410, 842-847.

11. Galaktionov, K., Lee, A. K., Eckstein, J., Draetta, G., Meckler, J., Loda, M. and Beach, D. 1995. CDC25 phosphatases as potential human oncogenes. Science 269, 1575-1577.

12. Gasparotto, D., Maestro, R., Piccinin, S., Vukosavljevic, T., Barzan, L., Sulfaro, S. and Boiocchi, M. 1997. Overexpression of CDC25A and CDC25B in head and neck cancers. Cancer Res 57, 2366-2368.

13. Guo, W. Q., He, Z. Y. and Zhang, Q. 2013. The anti-tumour effect of ethanol extract of rhizoma atractylodis on lung cancer A549 cells. Biotechnology 23, 73-76.

14. Hartwell, L. H. and Kastan, M. B. 1994. Cell cycle control and cancer. Science 266, 1821-1828.

15. Hashimoto, O., Ueno, T., Kimura, R., Ohtsubo, M., Nakamura, T., Koga, H., Torimura, T., Uchida, S., Yamashita, K. and Sata, M. 2003. Inhibition of proteasome-dependent degradation of Wee1 in G2-arrested Hep3B cells by TGF beta 1. Mol Carcinog 36, 171-182.

16. Hoeijmakers, J. H. 2001. Genome maintenance mechanisms for preventing cancer. Nature 411, 366-374.

17. Ito, Y., Yoshida, H., Uruno, T., Takamura, Y., Miya, A., Kuma, K. K. and Miyauchi, A. 2004. Expression of cdc25A and cdc25B phosphatase in breast carcinoma. Breast Cancer 11, 295-300.

18. Jemal, A., Bray, F., Center, M. M., Ferlay, J., Ward, E. and Forman, D. 2011. Global cancer statistics. CA Cancer J Clin 61, 69-90.

19. Jin, P., Gu, Y. and Morgan, D. O. 1996. Role of inhibitory CDC2 phosphorylation in radiation-induced G2 arrest in human cells. J Cell Biol 134, 963-970.

20. Kim, D. Y. and Ghil, S. H. 2009. Effect of Lycopus lucidus Trucz on cell growth of human breast cancer cells, MCF-7. J Exp Biomed Sci 15, 147-152.

21. Kim, W. H., Kim, J. W., Jang, S. M., Song, K. H., Ham, S. W. and Choi, K. H. 2007. Naphthoquinone Analog-induced G1 arrest is mediated by cdc25A inhibition and p53-independent p21 induction in human hepatocarcinoma cells. Integr Biosci 11, 9-15.

22. Lee, Y. J., Kang, D. G., Kim, J. S. and Lee, H. S. 2008. Lycopus lucidus inhibits high glucose-induced vascular inflammation in human umbilical vein endothelial cells. Vascul Pharmacol 48, 38-46.

23. Mailand, N., Falck, J., Lukas, C., Syljuâsen, R. G., Welcker, M., Bartek, J. and Lukas, J. 2000. Rapid destruction of Cdc25A in response to DNA damage. Science 288, 1425-1429.

24. Nalca, A. and Rangnekar, V. M. 1998. The G1-phase growtharresting action of interleukin-1 is independent of p53 and
p21/WAF1 function. J Biol Chem 273, 30517-30523.

25. Neergheen, V. S., Bahorun, T., Taylor, E. W., Jen, L. S. and Aruoma, O. I. 2010. Targeting specific cell signaling transduction pathways by dietary and medicinal phytochemicals in cancer chemoprevention. Toxicology 278, 229-241.

26. Nilsson, I. and Hoffmann, I. 2000. Cell cycle regulation by the Cdc25 phosphatase family. Prog Cell Cycle Res 4, 107-114.

27. O'Connor, P. M. 1997. Mammalian G1 and G2 phase checkpoints. Cancer Surv 29, 151-182.

28. Park, J. H. 2004. Medicinal plants of Korean, pp. 1171-1173, Shinil Books: Seoul, Korea.

29. Polewska, J., Skwarska, A., Augustin, E. and Konopa, J. 2013. DNA-damaging imidazoacridinone C-1311 induces autophagy followed by irreversible growth arrest and senescence in human lung cancer cells. J Pharmacol Exp Ther 346, 393-405.

30. Ryan, K. M., Phillips, A. C. and Vousden, K. H. 2001. Regulation and function of the p53 tumor suppressor protein. Curr Opin Cell Biol 13, 332-337.

31. Shin, T. Y., Kim, S. H., Suk, K. H., Ha, J. H., Kim, I. K., Lee, M. G., Jun, C. D., Kim, S. Y., Lim, J. P., Eun, J. S., Shin, H. Y. and Kim, H. M. 2005. Anti-allergic effects of Lycopus lucidus on mast cell-mediated allergy model. Toxicol Appl Pharmacol 209, 255-262.

32. Vogelstein, B., Lane, D. and Levine, A. J. 2000. Surfing the p53 network. Nature 408, 307-310.

33. Woo, E. R. and Piao, M. S. 2004. Antioxidative constituents from Lycopus lucidus. Arch Pharmacal Res 27, 173-176.

34. Wu, W., Fan, Y. H., Kemp, B. L., Walsh, G. and Mao, L. 1998. Overexpression of cdc $25 \mathrm{~A}$ and cdc25B is frequent in primary non-small cell lung cancer but is not associated with overexpression of c-myc. Cancer Res 58, 4082-4085.

35. Xu, X., Yamamoto, H., Liu, G., Ito, Y., Ngan, C. Y., Kondo, M., Nagano, H., Dono, K., Sekimoto, M. and Monden, M. 2008. CDC25A inhibition suppresses the growth and invasion of human hepatocellular carcinoma cells. Int $\mathrm{J} \mathrm{Mol}$ Med 21, 145-152.

36. Xu, X., Yamamoto, H., Sakon, M., Yasui, M., Ngan, C. Y., Fukunaga, H., Morita, T., Ogawa, M., Nagano, H., Nakamori, S., Sekimoto, M., Matsuura, N. and Monden, M. 2003. Overexpression of CDC25A phosphatase is associated with hypergrowth activity and poor prognosis of human hepatocellular carcinomas. Clin Cancer Res 9, 1764-1772.

37. Yun, Y., Han, S., Park, E., Yim, D., Lee, S., Lee, C. K., Cho, K. and Kim, K. 2003. Immunomodulatory activity of betulinic acid by producing proinflammatory cytokines and activation of macrophages. Arch Pharmacal Res 26, 1087-1095.

38. Zhang, W., Grasso, L., McClain, C. D., Gambel, A. M., Cha, Y., Travali, S., Deisseroth, A. B. and Mercer, W. E. 1995. p53-independent induction of WAF1/CIP1 in human leukemia cells is correlated with growth arrest accompanying monocyte/macrophage differentiation. Cancer Res 55, 668674.

39. Zhou, B. B. and Elledge, S. J. 2000. The DNA damage response: putting checkpoints in perspective. Nature 408, 433-439. 
초록 : 택란 메탄올 추출물에 의한 인체 폐암 세포주 A549의 G1 arrest 유발

박현진 ${ }^{1} \cdot$ 진수정 ${ }^{1} \cdot$ 오유나 ${ }^{1} \cdot$ 윤승근 ${ }^{2} \cdot$ 이지영 ${ }^{1} \cdot$ 권현주 $^{1,2} \cdot$ 김병우 ${ }^{1,2}$ *

('동의대학교 블루바이오 소재개발 센터, ${ }^{2}$ 동의대학교 자연과학대학 생명응용학과)

본 연구에서는 인체 폐암 세포인 A549를 사용하여 택란 메탄올 추출물의 항암활성과 그 분자적 기전에 관하여 연구하였다. 먼저 택란 추출물이 A549의 세포증식에 미치는 영향을 알아본 결과 처리 농도 및 시간 의존적으로 A549의 성장이 저해되었으며, 세포 주기 변화를 분석한 결과 강력한 G1 arrest가 유도되는 것을 확인하였다. 이러 한 택란 추출물에 의한 G1 arrest는 세포주기 조절 단백질인 Cyclin D1, Cyclin E 및 Cyclin-dependent kinase인 $\mathrm{CDK} 2, \mathrm{CDK} 4, \mathrm{CDK} 6$ 의 발현 감소와 연관되어 있었다. 또한 택란 추출물에 의한 CDK/Cyclin complex의 발현 저해는 DNA 손상에 의해 활성화되는 CHK2의 활성화 형태인 p-CHK2의 발현 증가에 따른 CDK 활성화 효소인 Cdc25A phosphatase의 발현 억제에 의해 나타나는 결과로 사료된다. 반면 종양억제유전자인 p53 및 CDK 억제제 인 p21과 p27의 발현량은 증가되지 않았다. 이러한 결과들로부터 택란 추출물은 DNA damage에 의한 $\mathrm{ATM} / \mathrm{CHK} 2 / \mathrm{Cdc} 25 \mathrm{~A} / \mathrm{CDK} 2$ pathway를 통해 A549의 G1 arrest를 유도하여 세포의 증식을 억제할 것으로 판단 되며, 이때 택란 추출물에 의해 유도되는 G1 arrest는 p53 비의존적인 경로일 것으로 사료된다. 본 연구결과는 택란이 Cdc25A를 target으로 하는 새로운 항암활성 소재로서 사용될 수 있는 가능성을 시사한다. 또한 본 연구결 과는 택란 추출물의 세포주기 조절에 의한 항암기전을 이해하고 향후 지속적 연구를 하는 데 있어서 귀중한 기초 자료로 사용될 수 있을 것이다. 